\title{
Ordoliberalism, Pragmatism and the Eurozone Crisis: How the German Tradition Shaped Economic Policy in Europe
}

\author{
Lars P. Feld \\ Ekkehard A. Köhler \\ Daniel Nientiedt
}

CESIFO WORKING PAPER NO. 5368

CATEgory 2: Public CHOICE

MAY 2015

An electronic version of the paper may be downloaded

- from the SSRN website:

- from the RePEc website:

- from the CESifo website:

wWw.SSRN.com

Www.RePEc.org

www.CESifo-group.org/wp 


\title{
Ordoliberalism, Pragmatism and the Eurozone Crisis: How the German Tradition Shaped Economic Policy in Europe
}

\begin{abstract}
German policy during the Eurozone crisis supposedly follows an ordoliberal tradition. In this paper, we discuss to what extent this contention holds and to what extent Germany pragmatically responded to different crisis phenomena. A proper analysis of ordoliberal thinking reveals that the European Monetary Union can be justified on ordoliberal grounds as an economic constitution for Europe in which several pillars supposedly aim at ensuring sound money in the Eurozone. The policies the German government pushed during the Eurozone crisis have been informed by the ordoliberal tradition. In particular, this tradition may explain why the German government has been hesitant to support the call for Eurobonds and has only reluctantly established the European Stability Mechanism (ESM). However, the decisions on the ESM and the acceptance of unconventional monetary policy in Europe show that German economic policy largely responded pragmatically to the challenges offered by the crisis.
\end{abstract}

JEL-Code: B130, B260, B310, D780, E610, E630.

Keywords: ordoliberalism, Eurozone crisis, constitutional economics, monetary and fiscal policy.

\author{
Lars P. Feld* \\ University of Freiburg \& Walter Eucken Institute \\ Goethestrasse 10 \\ Germany - 79100 Freiburg \\ feld@eucken.de
}

Ekkehard A. Köhler

Walter Eucken Institute

Goethestrasse 10

Germany - 79100 Freiburg

koehler@eucken.de

\author{
Daniel Nientiedt \\ University of Freiburg \& \\ Walter Eucken Institute \\ Goethestrasse 10 \\ Germany - 79100 Freiburg \\ nientiedt@eucken.de
}

*corresponding author

This version: May 18, 2015. - We thank the participants of the Roundtable Discussion on ,Ordoliberalism and the Political Economy of Crisis' at the 8th Pan-European Conference on International Relations, Warzsaw (Poland), September 18 - 21, 2013, those of a conference on legitimity of economic constitutions held in January 30 - 31, 2015 in Schloss Ettersburg at Weimar (Germany) and three anonymous referees for their comments and suggestions. 


\section{Introduction}

During the Eurozone crisis, Germany has often been accused of pursuing macroeconomic policy that is too much focused on maintaining price stability and fiscal austerity rather than stimulating growth. Although this accusation is not correct, ${ }^{1}$ public opinion has attributed the hardship experienced in the deficit countries to Angela Merkel's government. Those interested in understanding why this policy emerged have detected that Germany has the particular political-economic tradition of Ordoliberalism that may still guide Germany's approach to the Euro crisis today (Dullien and Guerot, 2012). Moreover, German Ordoliberalism has recently been denounced of being "the wacky economics of Germany's parallel universe" (Wolfgang Munchau, FT, 17 November 2014) or as a form of "economic narcissism" (Hans Kundnami, The Guardian, 6 January 2012). ${ }^{2}$ Most participants in such public debates have assessed Ordoliberalism in strong statements, either without knowing ordoliberal thinking at all or, less severe, without properly addressing its intellectual roots and evolution over time. The aim of this paper thus is to shed light on Ordoliberalism's view of macroeconomic issues drawing on the evolution of this thinking from the 1930s to date.

Ordoliberalism originates from the so-called "Freiburg School" of the 1930s, a research programme at Freiburg University led by economist Walter Eucken and law scholar Franz Böhm. Their aim was to investigate the interdependency of legal-institutional structures and economics. ${ }^{3}$ In his book “Grundsätze der Wirtschaftspolitik” (Principles of Economic Policy), Eucken (1952/2004) distinguishes the policy-type of "Ordnungspolitik" from interventionist policy-making. According to this ideal distinction, the government should provide a rule-based (constitutional) framework to shape markets, but should not intervene in day-to-day economic decisions. As for the properties of the framework, Eucken was convinced that a prudent economic constitution must be based on constitutive principles, one of them being monetary stability (the "primacy of currency policy"). The importance of stable money in Eucken's work

\footnotetext{
${ }^{1}$ Each excessively indebted country would have had to consolidate its budget during the Eurozone debt crisis because their creditors and taxpayers lacked the willingness to finance further deficits in those countries. The proponents of the view that Germany should end "austerity" count on the German taxpayer paying for the debt of its European partners when no one else is willing to pay for it.

${ }^{2}$ See also the following contributions from The Economist: Slow, but popular (8 December 2012), Ordoliberalism revisited (18 October 2014), The sputtering engine (22 November 2014) and Of rules and order (9 May 2015, Vol. 415, No. 8937, pp. 21-22).

${ }^{3}$ For an introduction to the Freiburg School, see Vanberg (2004). The Freiburg School is one branch of German Ordoliberalism in addition to the conservative Ordoliberalism of Wilhelm Röpke and Alexander Rüstow as well as the social Ordoliberalism of Alfred Müller-Armack.
} 
is taken as support of the claim that current German macroeconomic policy corresponds to ordoliberal thinking (Weidmann 2014). However, this interpretation is incomplete and does not consider the heterogeneity and evolution of ordoliberal thinking over time.

In this paper, we want to discuss the roots of German economic policy in several respects. We first review the literature on Germany's alleged "ordoliberal” approach to the Eurozone crisis and summarize this distinct debate (Section 2). We then trace the development of German monetary policy from the Freiburg School of the 1930s to the eve of the European Monetary Union (EMU). We will underline how and to what extent Keynesian thinking and Monetarism have supplemented Ordoliberalism (Section 3). Next, we discuss the policy-type of Ordnungspolitik and illustrate its persistence in German economic policy debates in two ways (Section 4). First, we will interpret the main elements of EMU as an economic constitution for Europe in which several pillars supposedly aim at ensuring sound money in the Eurozone. Second, we will show which policies the German government pushed during the Great Recession and the Eurozone crisis and to what extent the ordoliberal tradition has informed them. For example, this tradition may explain why the German government has been hesitant to support the call for Eurobonds and has only reluctantly established the European Stability Mechanism (ESM). ${ }^{4}$ The final part of the paper will show how alternative policies, probably more consistent with ordoliberal principles, could look like (Section 5). We conclude with a summary and some concluding remarks (Section 6).

\section{A return of Ordoliberalism in Europe?}

Germany is usually regarded as having a relatively strong impact on the development of EMU, especially in the aftermath of the Eurozone crisis (Bulmer and Paterson, 2013). This observation has given rise to new interest in the different intellectual traditions that have shaped the German approach to economic policy, in particular the Freiburg School of Ordoliberalism. According to the survey by Thomas Biebricher, the contribution of the Freiburg School has been rediscovered as a topic of research by social scientists in different contexts, one of them being

\footnotetext{
${ }^{4}$ Similarly, this tradition helps to understand why Germany pushed its partners to accept further restrictions on their fiscal policies by the Fiscal Compact. The adjustment programmes in the Eurozone countries in trouble, in particular Greece, Ireland, Portugal and Spain, can however not be attributed to a special German political-economic tradition as they are designed along the lines of IMF adjustment programmes undertaken in the past.
} 
the "ordoliberal reshaping of European economic governance structures in response to the sovereign debt crisis" (Biebricher, 2014, p. 3). ${ }^{5}$ Obviously, the notion that recent institutional changes in response to the crisis are to be considered ordoliberal in nature requires further explanation. What is ordoliberal about them? And how did the reception of Eucken's ideas come about? While the first question is concerned with the ordoliberal character of the reforms, the second question concerns the transmission of ordoliberal thought and, more broadly, the history of ideas and their influence on real-world politics.

The hypothesis of an "ordoliberalization of Europe" (Blyth, 2013, p. 142) primarily rests on the assumption of a specific German approach to monetary policy combined with its implications for fiscal discipline. ${ }^{6}$ Volker Berghahn and Brigitte Young put it as follows: "In the present Euro crisis, the influence of Ordoliberalism is most evident in the German position on price stability and its defence of the independence of the Central Bank. Both the Maastricht Agreement and the accompanying Stability and Growth Treaty bear the handwriting of the Germans. This is not new, it is the legacy of the Deutsche Bundesbank; the Freiburgers argued for the primacy of currency policy" (Berghahn and Young, 2012, p. 9). According to this argument, German monetary policy can be characterised by a strong anti-inflationary bias rooted in the ordoliberal tradition - a view shared by Biebricher (2014, pp. 8-9), Blyth (2013, p. 141), Bonefeld (2013, p. 782), Bulmer and Paterson (2013, p. 1397), Young (2014), as well as Commun (2014, p. 27).

The importance of price stability has implications for the perspective on fiscal policy as well. In his survey, Biebricher claims that the German position on monetary issues prohibits them from supporting much-needed policies of fiscal stimulus for Eurozone countries faced with high unemployment and low growth rates (Biebricher, 2014, pp. 8-9). Similarly, Mark Blyth asserts that "there is no place for Keynes [...] in an economic union in which competition produces growth through the production of competitive goods and the running of surpluses, not the shallow demand of the money press" (Blyth, 2013, p. 143). Thus, the controversial austerity measures and structural reforms performed by countries dealing with sovereign debt are seen as a logical consequence of the overarching aim of preserving sound money.

\footnotetext{
${ }^{5}$ The other two contexts are the field of governmentality studies as well as the re-regulation of financial markets (Biebricher, 2014, pp. 3-7).

${ }^{6}$ This literature is surprisingly detached from earlier receptions of Ordoliberalism, e.g., Sally (1996).
} 
Although the assumption of a specific German approach to monetary issues is at the very heart of the discussion, there are a couple of related arguments. First, competitiveness is understood both as the goal of current reforms and as a prescription of ordoliberal thinking. For example, Blyth maintains that "the consistent focus on the periphery states' loss of competitiveness and the need for deep wage and cost reduction therein [...] speaks to a deeply ordoliberal understanding of economic management" (Blyth, 2013, p. 141). Biebricher, too, presents competitiveness as an ordoliberal mantra (Biebricher, 2014, pp. 7-8). Both authors fail to mention the role of fixed exchange rates in a monetary union (see Section 4).

Second, it is suggested that the ordoliberal concept of the state contributes to what is perceived as "an authoritarian, undemocratic and technocratic turn in European governance" (Biebricher, 2013, p. 345), raising the question of political legitimacy. This argument ties into the longstanding discussion as to whether Eucken's theory presupposes a less-than-democratic system of government. ${ }^{7}$ In the current debate on the Eurozone crisis, Werner Bonefeld has reemphasized the idea that "ordoliberals conceive of the agents of the strong state as modern day aristocrats of the common good" (Bonefeld, 2012, p. 650). While Eucken's concept of democracy is beyond the scope of this paper, it should be separated from the constitutional development of modern-day Europe. Even without recourse to Ordoliberalism, there are good reasons to demand a more democratic European Union in which policy outcomes are more strongly oriented at citizens' preferences (Feld, 2005).

\section{Remarks on the development of German monetary policy}

The specific German approach to monetary policy is supposedly rooted in Ordoliberalism. If we take this belief as a hypothesis and discuss it from the perspective of the history of economic thought, the following questions arise: First, who are the relevant ordoliberal thinkers and what are their key ideas and proposals for a post-war (monetary) economic constitution? Second, has their influence prevailed across time?

\footnotetext{
${ }^{7}$ Eucken opted for methodological reasons to take the outcome of the political process as given (Eucken, 1940/1950, pp. 213-216), leaving his concept of the state largely unexplained. This has been interpreted to conceal an authoritarian conviction (e.g., Kirchgässner, 1988). For a recent evaluation of Eucken's stance on democracy, countering the accusation of authoritarianism, see Nientiedt and Köhler (2014).
} 


\subsection{The Freiburg School's perspective on monetary policy}

The roots of monetary thinking in Ordoliberalism can be traced back to the early 1920s. Trying to overcome the "Great Antinomy" between historical and theoretical social science, Eucken develops an institutional approach to economics as exemplified in his first two books on monetary policy (Eucken, 1923, 1925). In these works, Eucken focuses on the level of rules as the main unit for economic analysis and the locus for monetary reform. After he had experienced the hyperinflation and the deflation of the Weimar Republic, Eucken defined the objective of the ordoliberal quest for an appropriate monetary constitution by posing the "great question of economic policy how a monetary constitution of greater stability can be integrated into the competitive order" (Eucken, 1952/2004, p. 259). ${ }^{8}$ Countering his colleagues from the historical school, Eucken developed a theory that distinguishes between three types of monetary systems. While in the case of the first and second system the emergence of money is tied to a physical standard, in the third system money is created via an extension of credit by either a central bank or commercial banks, making the supply of money extremely elastic, but eventually unstable (Eucken, 1940/1950, pp. 169-172). Eucken's critical assessment of the third monetary system lead him to consider the solution of a commodity reserve currency (Eucken, 1952/2004, pp. 261-264). ${ }^{9}$ In a system with commodity-backed currency, money supply depends on the change of commodity prices rather than the monetary authority's discretionary decision-making. This is a crucial point in Eucken's argumentation: Money supply should not be subject to political manipulation, but take the form of a "rational automatism" (ibid, p. 263) that adjusts according to agreed-upon rules.

Eucken's doctoral student Friedrich Lutz (1936) offered a theoretical basis for the characteristics of the third monetary system and consequently declared his support for banking reforms outlined in the so-called Chicago plan of the early $1930 \mathrm{~s} .{ }^{10}$ Following the arguments of Chicago economists such as Henry Simons, Lutz argued that the central bank should be the only institution to control money supply. In contrast, commercial banks should be limited in their ability to issue money by forcing them to hold a 100 percent reserve ratio in central bank money. ${ }^{11}$ Thus, the process of bank lending would effectively be decoupled from the creation

\footnotetext{
${ }^{8}$ All translations by the authors, unless indicated otherwise.

${ }^{9}$ For both a description and a critique of commodity reserve currencies, see Friedman (1951).

${ }^{10}$ For the similarities between the research programmes in Chicago and Freiburg in the 1930s, see Köhler and Kolev (2013).

${ }^{11}$ This rule requires that "all institutions which maintain deposit liabilities and/or provide checking facilities (or any substitute) shall maintain reserves of 100 percent in cash and deposits with the Federal Reserve banks" (Simons, 1934/1948, p. 62).
} 
of money. Eucken was sceptical of Lutz' proposal because it lacks an automatic mechanism and gave too much leeway to discretionary monetary policy. Still, he considered combining 100 percent money with a commodity reserve currency (Eucken, 1952/2004, pp. 260-263).

Leonhard Miksch (1949a), another student of Eucken, differed from his colleagues in that he opted for a competitive monetary constitution instead of a monopolistic institutional design as supported by Eucken and Lutz. ${ }^{12}$ In Miksch's proposal, the role of the central bank is reduced to the control of the quality of the coins; the main task of this "metric monopoly" is to specify the emission standard that commercial banks have to comply with when participating in the process of money creation. The emission standard includes commodities such as gold and most noteworthy - commercial papers. The inclusion of the latter is meant to overcome the inherent deflationary tendency of "pure" gold currencies (Köhler 2015). As for the advantages of this system, Miksch emphasizes that a competitive arrangement cannot easily be misused for political reasons. His concept is reminiscent of Friedrich von Hayek's famous proposal for a “Denationalisation of Money" (Hayek, 1976/1990).

To sum up, the ordoliberal proposals for a monetary constitution bear little resemblance to the actual institutional design that was implemented with the founding of the Bank deutscher Länder in 1948 and the subsequent Bundesbank Act of $1957 .{ }^{13}$ Neither a commodity reserve currency nor the specifics of the Chicago Plan were introduced; and the large amount of discretionary power given to the German central bank contradicted Eucken's ideal of a "rational automatism" guiding monetary policy. Miksch (1949b) is the only member of the Freiburg School who argued in favour of central bank independence. While the distinguishing feature of the Bundesbank's institutional design - its high degree of independence - would ultimately prove conducive to sound money (Alesina and Summers, 1993), this feature is not essential to the monetary concepts of Ordoliberalism. ${ }^{14}$

\footnotetext{
${ }^{12}$ Mikschs influence on Ludwig Erhard at the 'Verwaltung für Wirtschaft' during the spring of 1948 has been recently discussed with new archival material (Feld and Köhler 2015). For a systematic analysis of Mikschs' contribution in the field of monetary and capital theory, see Köhler (2015).

${ }^{13}$ The Bundesbank was preceded by the Bank deutscher Länder (BdL), established by the Allies in 1948. It remained under Allied control until the summer of 1951, when the "Übergangsgesetz" (interim law) granted some independence to the BdL. The "Bundesbankgesetz" of 1957 constituted the German central bank, equipped with a large degree of independence (§12). For a discussion, see Bibow (2009). ${ }^{14}$ The concept of central bank independence is incorrectly attributed to Eucken (e.g., Starbatty, 1994, p. 248).
} 
Regarding the interplay between monetary and stabilisation policy, Terence Hutchison notes that "Eucken was critical of Keynesian ideas and of full employment as a policy objective, though not dogmatically so, as [...] he had supported proposals for government employment policies and credit expansion in the desperate situation of 1931" (Hutchison, 1979, p. 434). ${ }^{15}$ Eucken's position originates from his expectation that Keynesian employment policy distorts price signals (Eucken, 1952/2004, pp. 140-144). At the same time, the functioning of the price mechanism is seen as essential for the coordination of all economic activity (ibid, pp. 254-255). However, Eucken seemed to be convinced that a proper monetary constitution would actually achieve some of the goals of stabilisation policy (ibid, p. 311).

\subsection{The German discussion on monetary policy after the war}

In his comprehensive analysis of German monetary policy after the war, Rudolf Richter reports that the Bundesbank - although acting rather conservatively - did not adhere to a single policy of monetary stability in the early days, but rather communicated a bundle of different goals (Richter, 1999, pp. 19-20). More generally, he underlines that ordoliberal arguments did not play an important role in the monetary policy debates of the late 1940s and 1950s. After the deaths of Eucken and Miksch in 1950, Lutz was the most prominent representative of the Freiburg School working on monetary issues; however, his emphasis on the quantity theory of money made him an outsider in an intellectual environment already influenced by Keynesianism. Lutz was influential though in the discussion on fixed and flexible exchange rates initiated by the first report of the German Council of Economic Experts (GCEE, 1964), an advisory board to the German government. The report paved the way for Germany eventually leaving the Bretton Woods system ten years later (see Lutz and Sohmen, 1964).

In the 1960s, Keynesian ideas dominated the political agenda and economic thought. ${ }^{16}$ The neoclassical synthesis provided the theoretical background for the emerging policy concept of "Globalsteuerung", i.e., the coordinated application of various macroeconomic policies in an attempt to fine-tune economic growth over the business cycle. ${ }^{17}$ Richter notes that monetary

\footnotetext{
${ }^{15}$ Eucken was in support of the Lautenbach plan, a proposal aimed at preventing a liquidity trap in 1931.

${ }^{16}$ This can also be inferred by an analysis of the reports and the protocols of the Scientific Advisory Board to the German Federal Ministry of Economic Affairs. This advisory board was founded by Ludwig Erhard already in 1948. Eucken was a founding member. The board initially supported Erhard's ordoliberal reforms, then moved to the adoption of Keynesian ideas during the 1950s and 1960s.

${ }^{17}$ The approach of Globalsteuerung is best exemplified by the measures of the 1967 Law to Promote Economic Stability and Growth, in particular its declared aim to enable closer cooperation of the government, trade unions and employer associations ("Concerted Action"). Although Karl Schiller,
} 
policy was often regarded as being part of an overall concept of full employment policy. Specifically, the central bank was expected to foster economic growth by keeping interest rates low (Richter, 1999, pp. 48-50). In line with this approach, the Bundesbank employed a measure of bank liquidity to guide its monetary policy decisions. This policy was aimed at three goals simultaneously: Price stability, high employment and external balance (ibid, pp. 55-59). Notably, the German central bank deviated from the goal of price stability in order to boost aggregate demand: When confronted with the first recession after the war in 1967, the bank found it necessary to stabilize the business cycle by monetary measures (ibid, p. 65).

In the beginning of the 1970s, Monetarism emerged as a major intellectual force in the German discussion of monetary policy (see Giersch et al., 1992). Following the arguments brought forward by Milton Friedman and Karl Brunner, economists such as Hans Monissen and Manfred J.M. Neumann strongly recommended to take into account the expansion (or contraction) of the quantity of money as an indicator for monetary policy measures (e.g., Neumann, 1972). Monetarist theory also maintained that central banks should primarily be concerned with the stability of prices (see Friedman, 1968, pp. 14-17). When Germany had to redesign its monetary policy approach after the end of the Bretton Woods system in 1973, the Bundesbank accepted the monetarist prescription and chose monetary targeting as its modus operandi (Richter, 1999, p. 78). ${ }^{18}$ In 1974, the German central bank announced a money supply target for the first time - and continued to do so even after a number of central banks adopted inflation targeting in the 1990s. Thus, from the mid-seventies onwards, the Bundesbank followed a monetary policy rule reflecting the ideas of Friedman. ${ }^{19}$

By the time the Maastricht Treaty was signed in 1992, price stability had emerged as the sole objective of German monetary policy (Richter, 1999, p. 105). There were also new influences on monetary policy in the 1980s and 1990s. For example, it was supplemented by arguments from the perspective of New Institutional Economics, some of which reflected positions taken earlier by ordoliberal thinkers (Richter, 1988, 2012). Despite such similarities, it should have become clear that the development of German monetary policy must mainly be seen in the

\footnotetext{
Minister of Economic Affairs and the architect of Globalsteuerung, viewed his concept as a mere supplementation of the Freiburg imperative with Keynesian demand management, modern observers of this policy stress the dominance of Keynesianism (Hagemann, 2000, p. 115).

${ }^{18}$ Here, the German Council of Economic Experts was influential in developing concepts for monetary targeting. See GCEE (1973) for its monetarist turn.

${ }^{19}$ In practice, the Bundesbank appears to have been more flexible and incorporated inflation goals as well (see Bernanke and Mihov, 1997).
} 
context of the great (international) controversy between Keynesianism and Monetarism. For the most part, the strategy of the Bundesbank reflected the monetarist contention that there is no permanent trade-off between price stability on one side and growth or employment on the other side (see Friedman, 1968, pp. 7-11). ${ }^{20}$ Also, the main feature of Bundesbank policy - monetary targeting - is a monetarist concept. The Freiburg School's impact, on the other hand, was far less important than commonly assumed in the debate on the ordoliberal roots of the German approach to EMU. ${ }^{21}$

\section{Ordnungspolitik and its relevance to the German approach to the EMU}

The impact of the Freiburg School on post-war monetary policy discussion in Germany is - at best - marginal. While the distinct institutional set-up of EMU can hardly be traced back to the origins of ordoliberal monetary thinking, it can still be argued that the German perspective on EMU has been shaped by ordoliberal ideas in a more general sense. First, the rule-based focus in ordoliberal economic thought might very well describe the German stance during the Eurozone crisis. Second, Eucken's constitutive principles explain German resistance against joint liability.

\subsection{The persistence of rule-based Ordnungspolitik in German economic policy ${ }^{22}$}

Eucken (1952/2004, p. 242) distinguished the policy-type of "Ordnungspolitik" from interventionist policy-making. According to this ideal distinction, the government should provide a legal framework that shapes market outcomes, but should not intervene in day-to-day economic decisions. Today, Ordnungspolitik is perceived as the conviction that "the principal means by which economic policy can seek to improve 'the economy' is by improving the institutional framework within which economic activities take place" (Vanberg, 2014, p. 207). From this perspective, Ordnungspolitik is by no means a specific normative programme for economic policy; it is rather a way of addressing economic policy reform on the level of rules (Richter, 2012).

\footnotetext{
${ }^{20}$ Additionally, Germans have had a difficult relationship with the concept of inflation for most of the 20th century. Paul Samuelson famously remarked that whoever experienced the hyperinflation of the Weimar Republic could not discuss a compromise between price stability and growth (Samuelson, 1961, p. 677). Thus, the Bundesbank's strategy also reflected popular opinion.

${ }^{21}$ The discussion of concepts of monetary theory and policy stops in the beginning of the 1990s with the Maastricht Treaty because it is beyond the scope of this paper an provide an overview about monetary theory. For such an analysis, see Issing and Wieland (2013).

${ }^{22}$ This section builds on Feld (2012).
} 
It is this particular perspective on economic policy that has a long-standing tradition among German economists. The GCEE provides a good example; established in 1963 under Ludwig Erhard, then Minister of Economic Affairs, the GCEE came to play an important role in economic debates. Despite the changing macroeconomic paradigms, Olaf Sievert, a long-time member and former chairman of the GCEE, emphasizes that the council has always focused on the microeconomic foundations of economic activity as well as on ordoliberal - rather than interventionist - policy-making (Sievert, 2003, p. 35). Other prominent examples of German economists who argue in favour of Ordnungspolitik include the members of the Kronberger Kreis ${ }^{23}$ the Bundesbank, exemplified by their past presidents such as Hans Tietmeyer and their current president Jens Weidmann, as well as Hans-Werner Sinn, who reasoned at the height of the financial crisis that the US needed to subject their banks to a strong regulatory framework in the ordoliberal tradition (Sinn, 2009). ${ }^{24}$

From the perspective of Ordnungspolitik, Sievert (1993) expresses the rationale for EMU most clearly. A common currency in Europe provides money that governments cannot create, i.e., money that is removed from the political influence of the individual member states. This can readily be seen from the institutional design of EMU: The Maastricht Treaty and the Treaty of Lisbon commit the ECB to the goal of price stability. At the same time, it obtains a large degree of independence. Thus, the institutional design of the ECB is more similar to that of the Bundesbank than to any other central bank of the Eurozone (Alesina and Grilli, 1991). The national central banks are integrated into the European System of Central Banks, removing them from the pressures of national fiscal and employment policy. While conflicts of interest within the European nation states have in the past been dealt with at the expense of monetary stability, those conflicts are now to be handled without the use of monetary policy. As Wim Duisenberg put it, the Euro is "the first currency that has not only severed its link to gold, but also its link to the nation state" (quoted after Blankenburg et al., 2013, p. 463).

\footnotetext{
${ }^{23}$ The Kronberger Kreis is a circle of ordoliberal economists and lawyers founded in 1981. Lars Feld currently is speaker of this circle.

${ }^{24}$ Before he concluded his career as President of the Bundesbank, Hans Tietmeyer worked at the Federal Ministry of Economic Affairs from 1962 to 1982. From 1982 to 1989, he was Secretary of State in the Federal Finance Ministry. He drafted the law to establish the GCEE, drafted the so-called Lambsdorff paper that led to the break-up of the social-liberal coalition in 1982 (Feld, 2013), and was key in the negotiations for German unification and EMU. In 1988, he escaped an assassination attempt by the Rote Armee Fraktion (RAF). Another influential person in the Federal Ministry of Economic Affairs was Otto Schlecht. Both Tietmeyer and Schlecht were strongly influenced by Ordoliberalism when studying economics.
} 
Key to Sievert's argument for such a denationalised currency is the contention that "[the history of monetary systems] is primarily a varied history of the abuse of the right to create money" (Sievert, 1993, p. 14). He refers to two kinds of abuse: First, governments spend money they do not have by issuing currency. Not only is this kind of money devoid of any real basis; it used to be created at the expense of others (i.e. the citizenry). Secondly, governments devalue debt through inflation, placing the burden on their creditors. Sievert remarks that both kinds of behaviour have historically only been prevented by a single institutional arrangement, namely the gold standard. According to this analogy, the Maastricht Treaty creates an international monetary order for Europe that constitutes - above anything else $\mathrm{e}^{25}$ - an objectification of the money supply. ${ }^{26}$

There is another reason why the member states of EMU should not be able to devaluate their currency: Devaluation has historically been used as a means to improve the competitiveness of a country. This effect, however, is short-lived, because real economic conditions - the conditions that endanger competitiveness in the first place - remain unchanged. ${ }^{27}$ By design, a monetary union disposes of this possibility. With the introduction of a single currency, the countries of the Eurozone effectively entered a regime of fixed exchange rates (Mundell, 1961). While the nominal exchange rate is fixed, the real exchange rate between countries, i.e., the relation between the domestic and the foreign price level, can still be adjusted. Without the option of external devaluation, the relative competitiveness of a country within the monetary union must be ensured by the adjustment of wages and prices. ${ }^{28}$ Notably, the need for such adjustments cannot be attributed to any specific type of economic policy, ordoliberal or otherwise. It is rather connected to the internal logic of a monetary union.

While monetary policy is not conducted by individual members of EMU, fiscal policy as well as other measures of economic policy remain in national responsibility. Regarding fiscal policy, national responsibility should be ensured by the no-bailout clause (Art. 125 TFEU), i.e., the

\footnotetext{
${ }^{25}$ Another good reason for establishing EMU can be seen in the fact that a common currency reduces transaction costs (e.g., by the elimination of currency risk), fostering economic integration and exchange. For a discussion of the magnitude of this effect, see Rose (2000) or Berger and Nitsch (2008).

${ }^{26}$ See also Huerta de Soto (2012) who argues similarly.

${ }^{27}$ Such conditions typically entail wage or labour policies that increase unit labour costs, compromising the competitiveness of firms. A devaluation compensates for the disadvantage in unit labour costs only temporarily, but leads to increasing import prices and even more pressure on wages.

${ }^{28}$ Alternative mechanisms, which could replace nominal exchange rates as adjustment mechanisms, are labour mobility or fiscal transfers between different regions forming a currency union.
} 
principle that one member state does not accept liability for another member state, and the prohibition of monetary financing of fiscal policy (Art. 123 TFEU). Moreover, member states are responsible for their own employment policy. Given the constraints on monetary policy, real wages are entirely in the hands of the different interest groups of the labour market. The decentralized responsibility of the member states for important aspects of their economic policy is a constitutive feature of the monetary union and cannot be easily removed (Issing, 2008, pp. 186-190).

Since the member states have to pay their debt in money they cannot create, EMU should have a restrictive effect on fiscal policy (Sievert, 1993, p. 18). However, a common currency may also provide adverse incentives. The founders of the monetary union were well aware that some member states would be inclined to take advantage of the low interest rates that would be newly available to them (ibid, p. 19). They also knew that this kind of behaviour could become an obstacle to necessary adjustments and maintaining competitiveness. For this reason, the Maastricht criteria and later the Stability and Growth Pact (SGP) complement common monetary policy in order to counteract overly expansionary fiscal policy. From today's perspective, the standards for fiscal discipline were not sufficient. ${ }^{29}$ Nonetheless, they clearly reflect an attempt at creating a framework of rules that is aimed at ensuring sound fiscal policy as well as sound money.

\subsection{The German "no" to Eurobonds from the perspective of Ordnungspolitik}

Thinking in terms of orders has been exemplified by the description of EMU as an economic constitution for Europe. However, the ordoliberals of the Freiburg School offered more than a distinction between different types of economic policy. Rather, it was their goal to provide principles for the establishment of a "functioning and humane" economic constitution (Eucken, 1952/2004, p. 14). Given the thesis of an ordoliberalization of Europe, the obvious question arises whether these principles have been guiding Germany's response to the sovereign debt crisis.

According to Eucken, a proper economic constitution rests on seven constitutive principles (ibid, pp. 254-291). The "primacy of currency policy" is only the second constitutive principle; it is supposed to uphold the first or basic principle, namely the functioning of the price system.

\footnotetext{
${ }^{29}$ Notably, Germany was among the first countries to break these rules by not complying with the three percent limit of government deficit to GDP in the Maastricht criteria (Moog and Raffelhüschen, 2011).
} 
Other constitutive principles are open markets, private property, freedom of contract, liability and the constancy of economic policy. As Weidmann (2014) points out, EMU rests on two of these principles in particular: The primacy of currency policy and the principle of liability. The first refers to the objective of maintaining price stability (see also Issing, 2000). The second points to the necessity that the sovereign states within the monetary union have to be held responsible for their decisions, i.e., that they cannot impose the costs of their actions on others, especially in the field of fiscal policy.

Eucken's concept of liability can best be summarised by his contention that "whoever stands to benefit [from an action] should bear the damage" (Eucken, 1952/2004, p. 279). In cases in which liability ("Haftung”) and control ("Lenkungsbefugnis") are separated, Eucken expects that the absence of liability leads to a lack of care in individual planning (ibid, p. 282). His argument is based on his assumption that the degree of personal liability fundamentally changes the assessment of costs and risks (ibid, p. 280). ${ }^{30}$ Thus, the strong stance of Germany against bailouts of crisis-ridden EMU member states can be understood in accordance to the persistence of this constitutive principle. Contagion effects do not play any role in Eucken's concept. This is not surprising given the situation of financial markets in the interwar and war periods. During the Eurozone crisis, contagion has however been the main driving force to separate liability and control. Neglecting contagion may thus be seen as the main flaw of German ordoliberal thinking in response to the crisis.

Eucken's principles are in line with the positions Germany has taken during the sovereign debt crisis. In November 2011, the European Commission suggested jointly issued government bonds as a way to reduce refinancing costs of some of its members (European Commission, 2011). Given that such bonds would reduce liability and weaken the incentives for fiscal consolidation, the German government's resistance to this proposal may reflect ordoliberal precepts. Germany supported the creation of the ESM as a rescue mechanism for highly indebted countries, but criticized the institution on similar grounds: Weidmann referred to the ESM as a "major step in the direction of joint liability" because it is not accompanied by a corresponding transfer of fiscal authority to the European level (Weidmann, 2011). Merkel's government also pushed for the establishment of the Fiscal Compact aimed at reinforcing the budget discipline laid down in the SGP by introducing permanent "debt brakes" in the member states (Schnellenbach and Burret, 2013).

\footnotetext{
${ }^{30}$ The large literature on moral hazard confirms this suspicion.
} 
Paradoxically, the German opposition to Eurobonds led to monetary policy measures that do not conform with ordoliberal thinking. In the summer of 2012, the ECB announced its OMT programme aimed at purchasing bonds issued by Eurozone member states. This had become necessary because market participants questioned the sustainability of public finances and feared the effects of an involuntary break-up of the Eurozone (Asmussen, 2013). The OMT programme fundamentally changed market expectations, but it also contributed to the problem of reduced liability and missing incentives for consolidation. Additionally, the OMT programme has important ramifications for the independence of the central bank because it effectively combines monetary and fiscal policy measures (GCEE, 2013).

Thus, while the German government may have judged reform proposals on the basis of ordoliberal principles, they certainly did not achieve an outcome in line with these principles. In fact, the acceptance of both the ESM and the ECB's OMT programme seem to be driven by pragmatism rather than the insistence on ordoliberal doctrine: Germany accepted those policies in order to stabilize the monetary union in a time of deep crisis. German policy-makers had to accept that contagion threatened the very existence of EMU and reacted pragmatically.

Although the response to the sovereign debt crisis may be better described as pragmatic rather than ordoliberal, we suppose that the principles outlined above can actually be helpful in devising possible reforms for EMU. The reason for this is that the problem of liability is indeed a fundamental structural flaw of the currency union: It was the lack of credibility of the nobailout clause which in some cases allowed for the over-borrowing of the public sector. This problem of moral hazard could have been prevented if the market participants had been convinced that overly indebted countries would eventually default on their loans.

To sum up, the traditional rule-based perspective of Ordnungspolitik can explain the German stance against bailouts and further fiscal integration. The pragmatic response to the crisis, however, came at the cost of a loss of central bank independence as the ECB has increasingly been dragged in fiscal policy. Since independence is an important institutional arrangement to realize price stability, which is at the core of Eucken's constitutive principles, it might seem opaque why German policy traded independence for a strong stance against further fiscal integration. It would have been more consistent with rule-based economic thought to solve the fiscal crisis by a reform of the European fiscal constitution. Since EMU lacks such a fiscal 
constitution, it might become clear why traditional rule-based German thinking caused a dilemma in favour of pragmatism, eventually undermining central bank independence (GCEE, 2012).

\section{A proposal for reform: The constitutionalization of fiscal and monetary policy in}

\section{Europe}

A possible proposal that achieves both, reform of the monetary as well as the fiscal constitution, was submitted by the GCEE clearly taking into account contagion effects between member states during the crisis. In a recent report, the council outlines a reform proposal that places the principle of liability at the very heart of the reforms. In their Annual Economic Report 2013, the GCEE proposes a long-run institutional framework for the EMU (dubbed Maastricht 2.0) that relies on three pillars: Fiscal policy reforms, a crisis mechanism and financial market regulation. The council states that their concept "follows the basic principle of aligning liability and control at the same level in every relevant area of economic policy" (GCEE, 2013, p. 12).

The GCEE proposes to implement this basic principle as follows:

- Fiscal Policy: The proposal assumes that control over fiscal policy will remain a national responsibility for the time being. On this basis, liability can only be ensured by making the no-bailout clause credible again. According to the council, "fiscal misconduct should not be rewarded by a joint assumption of individual risks" (ibid, p. 13).

- Crisis Mechanism: The credibility of the no-bailout clause requires a debt-restructuring regime for countries who fail to comply with the conditions of the ESM. That the support of the ESM must be subject to such conditions follows from the initial rejection of joint liability.

- Financial Markets: Prior to the crisis, the regulation of financial markets was largely a national responsibility. However, banking distress in any single country of the integrated market can produce negative external effects for the financial systems of other countries. Moreover, the no-bailout clause, even if it is supplemented by a crisis mechanism, can only be credible as long as banks can sustain a restructuring of sovereign debt. Since a common currency establishes liability at the European level, but has to prepare the European banking system for a possible sovereign default, the council argues that an effective supervisory and resolution mechanism should be established. Eventually, this goal was reached with the banking union, a regulatory framework that does not differ much from the council's proposal. 
Obviously, the legacy debt problem prevents the implementation of a credible institutional framework for EMU along the lines of this proposal. There are not many options for reducing legacy debt in an environment with vulnerable financial markets. One feasible step towards this new institutional framework is offered by the proposal towards a European Redemption Pact (ERP) of which only one element is the European Redemption Fund (GCEE, 2012). In fact, the ERP rests on three pillars, (i) a European Redemption Fund, temporarily mutualising part of Eurozone debt; (ii) the Fiscal Compact, in particular a commitment to national debt brakes preferably at the constitutional level, collateral provided for the mutualised debt and earmarked taxes to service that debt; and (iii) the implementation of a crisis resolution mechanism with provisions for the possible involvement of the private sector in future crises.

When the GCEE proposed the ERP, the Eurozone was at the height of the crisis with large differences in yield spreads of member countries' sovereign bonds. The ERP would have reduced interest rates due to the mutualisation of debt in exchange for strong commitments to conduct structural reforms and consolidate public finances. The GCEE thought this mutual exchange to provide a transition regime to Maastricht 2.0 only, finally establishing a credible no-bailout regime with national sovereignty and responsibility for fiscal policy. Particularly, the GCEE designed the ERP realizing that otherwise the ECB would have to provide a monetary solution to ensure that EMU does not break apart. As member states could not agree on a fiscal solution along the lines of the GCEE's proposal, the ECB proposed the Outright Monetary Transactions (OMT) programme. With the ECB stepping in, the ERP has become obsolete (GCEE, 2013). ${ }^{31}$

Although this proposal of an ERP is only one of many proposals how to overcome the deadlock of fiscal and monetary reform, it has two advantages: The fund could reinstall a high degree of central bank independence and the pact could solve fiscal problems on the constitutional level. Even if it required a certain degree of further fiscal integration, German economic policy should not have been hesitant to seek a partial mutualisation of legacy debt when a disciplinary framework could be finally introduced. Thus, the ordoliberal principle of liability would be eventually installed while the onus of bailout would be shifted from the ECB to a debt restructuring mechanism. The alternative to this proposal is simply to accept that any further German "no" will simply be monetized by the ECB, a high price given the initial spark to

\footnotetext{
${ }^{31}$ See Corsetti et al. (2015) for an alternative proposal to cope with legacy debt in the world of OMT.
} 
ordoliberal thinking in the early 1920s when the Reichsbank inflated their way out of a debt overhang problem.

\section{Conclusion}

Germany's policy during the Eurozone crisis has been accused of following the wacky economics of Ordoliberalism, an outdated approach to economics without any use for modern day financial markets. In this paper, we have discussed to what extent Ordoliberalism has played a role for German economic policy in recent years. We have shown that German economic policy was simply a pragmatic response to different crisis phenomena in the sense of Karl Popper's piecemeal social engineering.

Analysing the history of economic thought in German (monetary) policy up to the adoption of the Maastricht Treaty, we have highlighted that the heterogeneous views of the members of the Freiburg School on monetary matters were not as important as Keynesianism and Monetarism. While the distinct institutional set-up of the ECB does not lend itself to an ordoliberal heritage, we have argued that important characteristics of EMU are in line with two of Eucken's constitutive principles for economic policy, namely sound money and liability.

German pragmatism during the crisis has caused an unintended break of basic principles of Ordoliberalism - surrendering EMU's de-politicized monetary constitution against the prevention of further fiscal integration on the EU level. Hence, the German "no" to Eurobonds was bought at the potential cost of the ordoliberal key principle of sound money. We conclude that Germany may have followed ordoliberal thinking rather too little than too much. It would have been more prudent to trade a partial (legacy) debt mutualisation against the preservation of independence of the ECB and national debt brakes. Ordoliberalism may thus not be as outdated as its opponents contend. 


\section{Bibliography}

Alesina, A., Grilli, V., 1991, The European Central Bank: Reshaping Monetary Politics in Europe, NBER Working Paper no. 3860.

Alesina, A., Summers, L., 1993, Central Bank Independence and Macroeconomic Performance: Some Comparative Evidence, Journal of Money, Credit and Banking 25, pp. 151-162.

Asmussen, J., 2013, Introductory Statement by the ECB in the Proceedings before the Federal Constitutional Court, Karlsruhe, 11 June 2013.

Berger, H., Nitsch, V., 2008, Zooming Out: The Trade Effect of the Euro in Historical Perspective, Journal of International Money and Finance 27, pp. 1244-1260.

Berghahn, V., Young, B., 2012, Reflections on Werner Bonefeld's 'Freedom and the Strong State: On German Ordoliberalism' and the Continuing Importance of the Ideas of Ordoliberalism to Understand Germany's (Contested) Role in Resolving the Eurozone Crisis, New Political Economy, DOI: 10.1080/13563467.2013.736959.

Bernanke, B., Mihov, I., 1997, What Does the Bundesbank Target?, European Economic Review 41, pp. 1025-1053.

Bibow, J., 2009, On the Origin and Rise of Central Bank Independence in West Germany, European Journal of the History of Economic Thought 16, pp. 155-190.

Biebricher, T., 2013, Europe and the Political Philosophy of Neoliberalism, Contemporary Political Theory 12, pp. 338-375.

Biebricher, T., 2014, The Return of Ordoliberalism in Europe - Notes on a Research Agenda, i-lex 9, pp. 1-24.

Blankenburg, S., King, L., Konzelmann, S., Wilkinson, F., 2013, Prospects for the Eurozone, Cambridge Journal of Economics 37, pp. 463-477. 
Blyth, M., 2013, Austerity: The History of a Dangerous Idea, Oxford, Oxford University Press.

Bonefeld, W., 2012, Freedom and the Strong State: On German Ordoliberalism, New Political Economy 17, pp. 633-656.

Bonefeld, W., 2013, On the Strong Liberal State: Beyond Berghahn and Young, New Political Economy 18, pp. 779-738.

Bulmer, S., Paterson, W., 2013, Germany as the EU's Reluctant Hegemon? Of Economic Strength and Political Constraints, Journal of European Public Policy 20, pp. 1387-1405.

Commun, P., 2014, German Ordoliberalism: Order vs. Disorder in Röpke’s Early Works, i-lex 9, pp. 27-39.

Corsetti, G., Feld, L.P., Lane, P.R., Reichlin, L., Rey, H., Vayanos, D., Weder di Mauro, B., 2015, A New Start for the Eurozone: Dealing with Debt, Monitoring the Eurozone, CEPR, London.

Dullien, S., Guerot, U., 2012, The Long Shadow of Ordoliberalism: Germany's Approach to the Euro Crisis, Policy Brief, European Council on Foreign Relations, ECFR/49, February 2012.

Eucken, W., 1923, Kritische Betrachtungen zum deutschen Geldproblem, Jena, Gustav Fischer.

Eucken, W., 1925, Das internationale Währungsproblem. Ein Überblick, Berlin, Gersbach und Sohn.

Eucken, W., 1940/1950, The Foundations of Economics: History and Theory in the Analysis of Economic Reality, London, William Hodge and Company.

Eucken, W., 1952/2004, Grundsätze der Wirtschaftspolitik, Tübingen, Mohr Siebeck.

European Commission, 2011, Green Paper on the Feasibility of Introducing Stability Bonds, COM (2011) 818. 
Feld, L.P., 2005, The European Constitution Project from the Perspective of Constitutional Political Economy, Public Choice 122, pp. 417-448.

Feld, L.P., 2012, Europa in der Welt von heute: Wilhelm Röpke und die Zukunft der Europäischen Währungsunion, ORDO 63, pp. 403-427.

Feld, L.P., 2013, Zur Bedeutung des „Manifests der Marktwirtschaft“, oder: das LambsdorffPapier im 31. Jahr, Zeitschrift für Wirtschaftspolitik 62, pp.227-243.

Feld, L.P., Köhler, E.A. (eds), 2015, Wettbewerbsordnung und Monopolbekämpfung: Zum Gedenken an Leonhard Miksch (1901 - 1950), Tübingen, Mohr Siebeck.

Friedman, M., 1951, Commodity-Reserve Currency, Journal of Political Economy 59, pp.203232.

Friedman, M., 1968, The Role of Monetary Policy, American Economic Review 58, pp.1-17.

German Council of Economic Experts, 1964, Stabiles Geld - Stetiges Wachstum, Annual Economic Report 1964/65, Stuttgart, Kohlhammer.

German Council of Economic Experts, 1973, Mut zur Stabilisierung, Annual Economic Report 1973/74, Stuttgart, Kohlhammer.

German Council of Economic Experts, 2012, After the Euro Area Summit: Time to Implement Long-term Solutions, English Version of the Special Report of the Council of Economic Experts, published on July 30, 2012.

German Council of Economic Experts, 2013, Gegen eine rückwärtsgewandte Wirtschaftspolitik, Annual Economic Report 2013/14, Wiesbaden, Statistisches Bundesamt.

Giersch, H., Paqué, K., Schmieding H., 1992, The Fading Miracle: Four Decades of Market Economy in Germany. Cambridge, Cambridge University Press, 2nd ed., revised 1994. 
Hagemann, H., 2000, The Post-1945 Development of Economics in Germany, pp.110-124 in Coats, A. (ed), 2000, The Development of Economics in Western Europe Since 1945, London, Routledge.

Hayek, F., 1976/1990, Denationalisation of Money - The Argument Refined, London, The Institute of Economic Affairs.

Huerta de Soto, J., 2012, Die Verteidigung des Euro: Ein österreichischer Ansatz, ORDO 63, pp. 21-44.

Hutchison, T., 1979, Notes on the Effects of Economic Ideas on Policy: The Example of the German Social Market Economy, Journal of Institutional and Theoretical Economics 135, pp. 426-441.

Issing, O., 2000, Walter Eucken: Vom Primat der Währungspolitik, Speech Given at the Walter Eucken Institut, Freiburg, 17 March 2000.

Issing, O., 2008, Der Euro: Geburt, Erfolg, Zukunft, Munich, Vahlen.

Issing, O., Wieland, V., 2013, Monetary Theory and Monetary Policy: Reflections on the Development over the Last 150 Years, Jahrbücher für Nationalökonomie und Statistik/ Journal of Economics and Statistics 233, pp. 423-445.

Kirchgässner, G., 1988, Wirtschaftspolitik und Politiksystem: Zur Kritik der traditionellen Ordnungstheorie aus der Sicht der Neuen Politischen Ökonomie, pp. 53-75 in Cassel, D., Ramb, B., Thieme, H. (eds), Ordnungspolitik, Munich, Vahlen.

Köhler, E.A.. 2015, Das geldtheoretische Denken und die Geldordnungsvorstellungen von Leonhard Miksch, pp. 61-80 in Feld, L.P., Köhler, E.A. (eds), 2015, Wettbewerbsordnung und Monopolbekämpfung: Zum Gedenken an Leonhard Miksch (1901 - 1950), Tübingen, Mohr Siebeck. 
Köhler, E.A., Kolev, S., 2013, The Conjoint Quest for a Liberal Positive Program, pp. 211-228 in Levy, D., Peart, S. (eds), 2013, The Modern Economy - Economic Organization and Activity, Basingstoke, Palgrave MacMillan.

Lutz, F., 1936, Das Grundproblem der Geldverfassung, Stuttgart, Kohlhammer.

Lutz, F., Sohmen, E., 1964, Wie kann sich ein Land der importierten Inflation entziehen, Gutachten im Auftrag des Sachverständigenrates, Anhang V, pp. 169-179 in: German Council of Economic Experts, Stabiles Geld - Wachstum, Annual Economic Report 1964/65, Stuttgart, Kohlhammer.

Miksch, L., 1949a, Die Geldordnung der Zukunft, Zeitschrift für das gesamte Kreditwesen 2, pp. 155-158.

Miksch, L., 1949b, Die künftige Bundes-Bank, Zeitschrift für das gesamte Kreditwesen 2, pp. 517-519.

Moog, S., Raffelhüschen, B., 2011, Ehrbare Staaten? Tatsächliche Staatsverschuldung in Europa im Vergleich, Argumente zu Marktwirtschaft und Politik No. 115, Berlin, Stiftung Marktwirtschaft.

Mundell, R., 1961, A Theory of Optimum Currency Areas, American Economic Review 51, pp. 657-665.

Neumann, M., 1972, Bank Liquidity and the Extended Monetary Base as Indicators of German Monetary Policy, pp. 165-217 in Brunner, K. (ed), 1972, Proceedings of the First Konstanzer Seminar on Monetary Theory and Monetary Policy, Berlin, Duncker \& Humblot.

Nientiedt, D., Köhler, E., 2014, Liberalism and Democracy - A Comparative Reading of Eucken and Hayek, Walter Eucken Institut, mimeo.

Richter, R., 1988, The New Institutional Economics Applied to Monetary Economics, Journal of Institutional and Theoretical Economics 144, pp. 208-224. 
Richter, R., 1999, Deutsche Geldpolitik 1948-1998, Tübingen, Mohr Siebeck.

Richter, R., 2012, German "Ordnungstheorie" from the Perspective of the New Institutional Economics, Schmollers Jahrbuch 132, pp. 473-499.

Rose, A., 2000, One Money, One Market: The Effect of Common Currencies on Trade, Economic Policy 15, pp. 7-45.

Sally, R., 1996, Ordoliberalism and the Social Market: Classical Political Economy from Germany, New Political Economy 1, pp. 233-257.

Samuelson, P., 1961, Die Wirtschaftswissenschaft in Amerika, Journal of Institutional and Theoretical Economics 117, pp. 658-678.

Schnellenbach, J., Burret, H., 2013, Implementation of the Fiscal Compact in the Euro Area Member States, German Council of Economic Experts Working Paper 08/2013.

Sievert, O., 1993, Geld, das man nicht selbst herstellen kann - Ein ordnungspolitisches Plädoyer für die Europäische Währungsunion, pp. 13-24 in Bofinger, P., Collignon, S., Lipp, E. (eds), 1993, Währungsunion oder Währungschaos? Was kommt nach der D-Mark, Wiesbaden, Gabler.

Sievert, O., 2003, Vom Keynesianismus zur Angebotspolitik, pp. 34-46 in Sachverständigenrat zur Begutachtung der gesamtwirtschaftlichen Entwicklung (eds), 2003, Vierzig Jahre Sachverständigenrat 1963-2003, Wiesbaden, Statistisches Bundesamt.

Simons, H., 1934/1948, A Positive Program for Laissez Faire: Some Proposals for a Liberal Economic Policy, pp. 40-77 in Simons, H., 1948, Economic Policy for a Free Society, Chicago, University of Chicago Press.

Sinn, H., 2009, Stuffing the Goose Strategy, ifo viewpoint No. 104.

Starbatty, J., 1994, Ordoliberalismus, pp. 239-254 in Issing, O. (ed), 1994, Geschichte der Nationalökonomie, 3rd edn, Munich, Vahlen. 
Vanberg, V., 2004, The Freiburg School: Walter Eucken and Ordoliberalism, Freiburg Discussion Papers on Constitutional Economics 04/11.

Vanberg, V., 2014, Ordnungspolitik, the Freiburg School and the Reason of Rules, i-lex 9, pp. 205-220.

Weidmann, J., 2011, Stellungnahme anlässlich der öffentlichen Anhörung des Haushaltsausschusses des Deutschen Bundestags zur Änderung des Gesetzes zur Übernahme von Gewährleistungen im Rahmen eines europäischen Stabilisierungsmechanismus, Berlin, 19 September 2011.

Weidmann, J., 2014, Marktwirtschaftliche Prinzipien in der Währungsunion, Acceptance Speech at the Wolfram Engels Prize Award Ceremony, Kronberg, 28 March 2014.

Young, B., 2014, German Ordoliberalism as Agenda Setter for the Euro Crisis: Myth Trumps Reality, forthcoming in: Journal of Comparative European Policy. 